\title{
Evaluation of Stress Distributions of Zirconia Connecting Screw in Bruxism: A Finite Element Analysis
}

\author{
Efe Can Sivrikaya(0000-0001-6798-7610) ${ }^{\alpha}$, Mehmet Sami Güler(0000-0003-0414-7707) ${ }^{\beta}$, \\ Muhammed Latif Bekci(0000-0003-4900-2739 ${ }^{v}$
}

Selcuk Dent J, 2021; 8: 617-622 (Doi: 10.15311/selcukdentj.729494)

Bașvuru Tarihi: 29 Nisan 2020

\section{ABSTRACT}

Evaluation of Stress Distributions of Zirconia Connecting Screw in Bruxism: A Finite Element Analysis

Background: The purpose of the present study was to evaluate the stress distributions of zirconia or titanium connecting screws under different loads (vertical and oblique) in bruxism patients and to indicate its applicability by comparing with physiological stress limit values.

Methods: Four different models were created in which the implants were the same size and design, with dental implant, abutment and connection screws made of zirconia or $\mathrm{Ti}$ (only screw). 3D-Finite element analysis (3D-FEA) was applied to study the effect of a vertical load $(1000 \mathrm{~N})$ and oblique load (an angle of $30^{\circ}$ ) on abutments in the models. The placement of implants are mandibular right first molar. Computerized tomography imaging of cadaver mandibles was used. Von Mises stresses of the different screw materials were compared with each other and the physiological stress limit values for zirconia.

Results: Von Mises stress values increased in oblique loading in all models. The von Mises stress values were significantly reduced in the titanium screw than zirconium under both loading simulations.

Conclusion: In patients with a high biting force physiological stress limit values for zirconia were not exceeded. Zircon connection screw may be used in patients with bruxism.

\section{KEYWORDS}

Zirconia is a ceramic oxide, with similar osseointegration and biocompatibility properties to $\mathrm{Ti}^{1}{ }^{1}$ At present, zirconia materials are favored in cases of a Ti allergy (estimated prevalence: $0.6 \%$ ), galvanic side effects, and esthetic requirements..$^{2-5}$ The biomechanical properties of materials affect stress formation. Under compression, ceramic materials are brittle and have limited tensile strength. ${ }^{6}$ Unlike $\mathrm{Ti}$ metals, they do not exhibit significant deformation before failure. ${ }^{6}$ Yttria-stabilized tetragonal zirconia polycrystal (Y-TZP), a type of ceramic is a suitable material for the manufacturing of dental implants. ${ }^{1,7,8}$

Bruxism can be defined as a parafunctional activity on the masticatory system during sleep or while awake

\section{ÖZ}

Bruksizm Hastalarında Zirkon Bağlantı Vidasının Stres Dağılımlarının Sonlu Elemanlar Analizi İle Değerlendirilmesi

Amaç: Çalışmanın amacı, bruksizm hastalarında farklı materyallerdeki implant-abutment bağlantı vidasında meydana gelen stress dağııımının değerlendirilmesidir. Ayrıca fizyolojik stress limit değerleri ile karşılaştırılarak uygulanabilirliğini belirtmektir.

Gereç ve Yöntemler: İmplantların, abutmentlerin ve bağlantı vidalarının aynı dizayn ve boyutta olduğu 4 model oluşturuldu. Bağlantı vidası titanium veya zircon olarak modellendi, diğer materyaller ise titanium olarak modellendi. Bruksizmli hastaların ısırma kuvvetinin taklidi için $1000 \mathrm{~N}$ dikey veya $30^{\circ}$ açılı yükleme abutmentlerin orta noktalarına uygulandı. Modellenen implant sağ mandibular birinci molar hizasındadır. Mandibulanın modellenmesinde kadavranın bilgisayarlı tomografi görüntüleri kullanıldı. Farklı bağlantı vidası materyallerinde meydana gelen (zircon veya titanium) von Mises stress değerleri karşılaştıııldı. Ayrıca zirkonyum bağlantı vidasındaki von Mises stress değerleri zirkonyumun fizyolojik stress limit değeri ile karşılaştırıldı.

Bulgular: Von Mises stres değerleri tüm modellerde $30^{\circ}$ açlı yüklemede artmıştır. Von Mises stres değerleri, her iki yükleme simülasyonunda titanyum vidada zirkonyuma göre önemli ölçüde azaldı.

Sonuç: Isırma kuvveti yüksek olan hastalarda zirkonyum fizyolojik stres limit değerleri aşılmamıştır. Bruksizm hastalarında zirkon bağlantı vidası kullanılmasında sakınca yoktur.

$\Delta N \Delta H T \Delta R$ KFI IMFI FR

and is characterized by teeth clenching. ${ }^{9,10}$ High bite strength of patients with bruxism causes implant, connection screw, abutment and surrounding bone stress. ${ }^{9}$ In a meta-analysis, Zhou et al. ${ }^{11}$ described that bruxism could cause technical complications, such as porcelain chipping, connection screw/implant loosening, connection screw/implant fracture. It also causes biological complications such as marginal bone loss or peri-implantitis. ${ }^{11}$ There are many studies that compare to stresses on different materials of implants and abutments in patients with bruxism. ${ }^{9,12}$ Although the connection screw fracture is a common phenomenon in the clinic, there is no study about stress analysis on different connection screws in patients with bruxism.

\footnotetext{
${ }^{\alpha}$ Karadeniz Technical University Faculty of Dentistry, Department of Oral Maxillofacial Surgery, Trabzon, Turkey

$\beta$ Ordu University Technical Sciences and Vocational School, Department of Machine and Metal Technologies, Ordu, Turkey

${ }^{v}$ Ordu University Technical Sciences and Vocational School, Department of Motor Vehicles and Transport Technologies, Ordu, Turkey
} 
The 3D-Finite element analysis (3D-FEA) method has become an increasingly useful tool for predicting the effects of stress values on implants system. ${ }^{1,13}$ In present study, zircon implant applied to mandibular first molar region. Von mises stress values of zirconia or titanium screw were evaluated using vertical and $30^{\circ}$ loading that mimic bruxism. The aim of this study was to evaluate the applicability of zircon connection screws at mandibular first molar region in patients with bruxism.

\section{MATERIALS AND METHODS}

3D-FEA models: Four implant systems were modelled, as below:

Model 1: A zirconia implant, zirconia abutment, zirconia connecting screw, and vertical load, Model 2: As in model 1 above but with an oblique load, Model 3: A zirconia implant, zirconia abutment, Ti connecting screw, and vertical load, Model 4: As in model 3 but with an oblique load.

Mandible, dental implant, abutment, and connection screw models: The mandible, implant, abutment, and connecting screw were transferred to a computer for 3D-FEA. Computerized tomography imaging of cadaver mandible was performed, and the data were transferred to a computer environment in DICOM format $(651 \mathrm{px} \times 651 \mathrm{px}, 96 \mathrm{kV}, 0.2 \mathrm{~mm}$ thickness; Aquillion 16, Toshiba, Tokyo, Japan). Using Mimics 10.01 (Materialise, Leuven, Belgium) and SolidWorks 15 (Solidworks Corporation, Waltham, MA, USA) software, a three-dimensional (3D) model of the mandible was created (vertical alveolar dimension 13 $\mathrm{mm}$ and lingual bone width greater than $6 \mathrm{~mm}$ ). Using the same software, an implant (diameter: $4.3 \mathrm{~mm}$, length: $11.5 \mathrm{~mm}$ ), abutment (Conical Connection $6 \times 7$ $\mathrm{mm})$ and connection screw $(7 \mathrm{~mm})$ was modeled according to the Nobel Active implant system (Nobel Active, Kloten, Switzerland)and placed vertically in FE models of the mandible to simulate in vivo conditions (Figure 1a)

3D-FEA: The models were exported to ANSYS Workbench 13 (Swanson ANSYS Inc., Houston, PA, USA. A mesh was automatically obtained using the same software (Figure 1b). The mesh contained 1963222 elements and 2341922 nodes. Those values were obtained according to the mean of all models. In this study, $100 \%$ implant-bone osseointegration was assumed.



Properties of the materials: The length, diameter, and design of the Y-TZP implants, Y-TZP abutments, and $\mathrm{Y}$-TZP or titanium connecting screws were the same in all models (Table 1).

Table 1.

\section{Young's Modulus (GPa) and Poisson's Ratio values used for the analyses. ${ }^{26-29}$}

\begin{tabular}{|ccc|}
\hline Material & Young Modulus (GPa) & Poison's Ratio \\
\hline Titanium & 110 & 0.35 \\
\hline Cortical bone & 13.7 & 0.30 \\
\hline Trabecular bone & 1.37 & 0.30 \\
\hline Y-TZP & 200 & 0.33 \\
\hline
\end{tabular}

Boundary conditions and loading: The boundary conditions were assumed to be fixed at each edge of the condyles, inferior border of the corpus, and distal border of the ramus as described previously. ${ }^{9}$ The applied forces were static.

The implants were loaded at 1,000 N vertically and then at a 30-degree angle onto the abutments (Figure 2). Vertical loading and $30^{\circ}$ loading were perpendicular to the midline. The implants were applied to the mandibular first molar tooth region. a.



b.



Figure 2

The models transferred to a computer environment (a). A mesh was obtained using the ANSYS 13 Workbench software placement (b). abutments.

\section{RESULTS}

In zirconia screw models von Mises values was 258.67 (Vertical loading)(Figure 3a) and 650.38 (Oblique loading) (Figure 3b). In titanium screw models von Mises values was $162.48^{*}$ (Vertical loading) (Figure $3 \mathrm{c}$ ) and $377.37^{*}$ (Oblique loading) (Figure $3 d$ ) von Mises stress values increased under an oblique load in all the models (Figure $3 \mathrm{~b}, \mathrm{c}>\mathrm{a}, \mathrm{b}$, Table 2). The von Mises stress values were relatively 
reduced in the titanium screw than zirconium under both loading simulations (Figure $3 a, b>c, d$, Table 2).

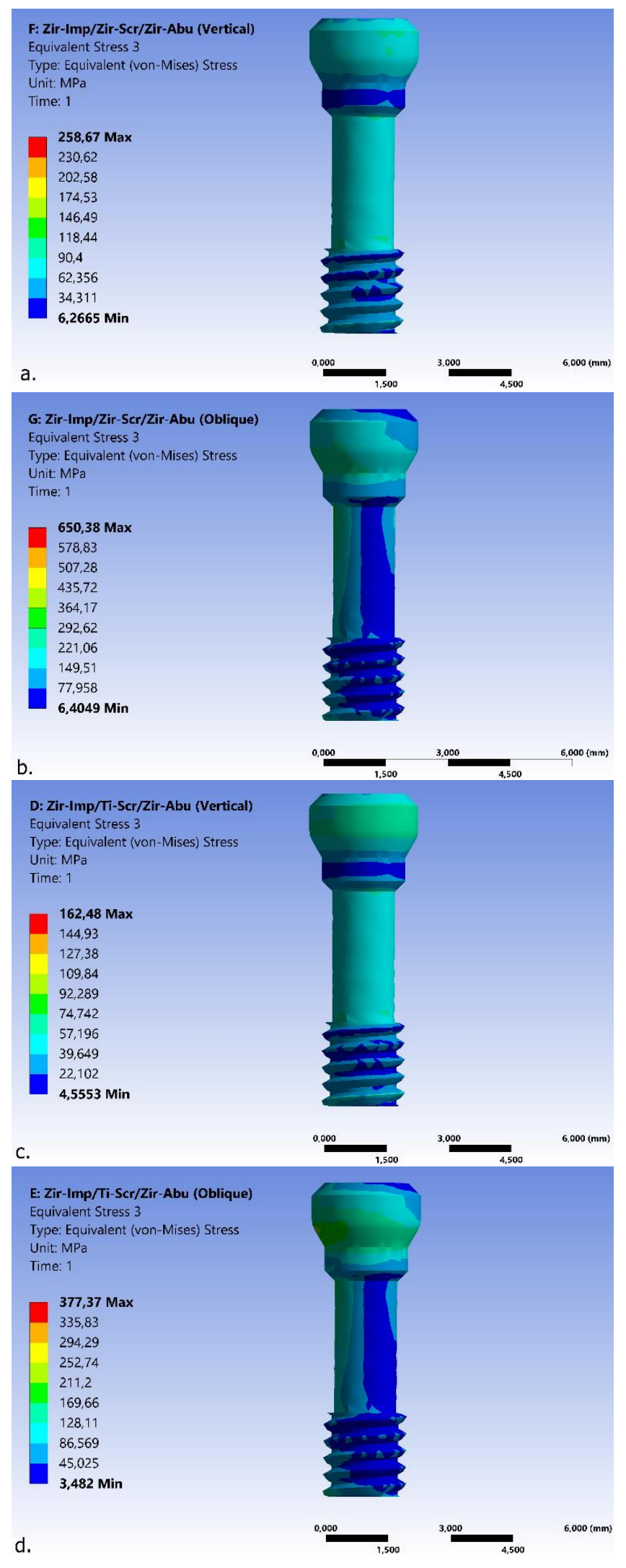

Figure 3

Von Mises stress values in connection screws under vertical and oblique loading. Model1 (a), Model2 (b), Model 3 (c), Model 4 (d).
Table 2.

Young's Modulus (GPa) and Poisson's Ratio values used for the analyses. ${ }^{26-29}$

\begin{tabular}{lccccc} 
& & Model 1 & Model 2 & Model 3 & Model 4 \\
\hline Screw & VMS & $258.67^{*}$ & $650.38^{*}$ & $162.48^{*}$ & $377.37^{*}$ \\
\hline Material & Z(I-A-S)v & Z(I-A-S)o & Z(I-A) T(S)v & Z(I-A-) T(S)o \\
\hline *: MPa VMS: Von Mises Stress PS:Principal Stress Z(I-A-S)V $=$ Implant, abutment and
\end{tabular}

connection screw are zirconia in vertical loads.

\section{DISCUSSION}

Zirconia are used as implant materials because of their osseointegration properties and biocompatibility. ${ }^{2-4,6}$ Due to the materials of $\mathrm{Ti}$ and zirconia, stress formation differs under an occlusal force, especially in patients with bruxism, where stress values increase. No studies in the literature have evaluated zirconia dental implants applied mandibular first molar region under heavy bruxing forces. In the present study, we compared the stresses in connection screws (Y-TZP or Ti) in bruxism patients using the 3D-FEA method. The ultimate aim of the study was to determine the effects of the material type (zirconium) on stress distribution values.

As described in the introduction, Zhou et al. et al. ${ }^{11}$ described that overload may occur easily in bruxers and it could cause technical and biological complications. Technical complications were ceramic chipping, framework misfit, porcelain fracture, acrylic resin base fracture, screw loosening, screw fracture, implant loss and abutment loosening. Biological complications were marginal bone loss and peri-implantitis. Similarly, there are several studies have reported that breakage of connection screws can occur, depending on the increase in biting force. ${ }^{14,15}$ According to Silva et al., ${ }^{15}$ the most important drawback of dental implant/abutment assemblies is the need for a fixing screw. One-piece abutments, morse tapers, and platform switching techniques have been developed to combat this problem. ${ }^{15,16}$ Previous studies demonstrated that zirconium materials had flexural strength at 900-1200 $\mathrm{MPa}^{13,17,18}$ and compression resistance at 2,000 $\mathrm{MPa} .{ }^{18}$ In the present study, the von Mises stress values were lowest in the connection screws between 162.48 and $377.37 \mathrm{MPa}$ under static loading, and the von Mises stress in the screws did not exceed the value at which micro-crack formation occurs (i.e., < 900-1200 MPa) (Table 2). However, screw-related complications may also occur due to dynamic loading. There is insufficient information in the literature on such complications.

In previous studies on patients with bruxism, the researchers analyzed forces of $200-2,500 \mathrm{~N} .9,19,20$ Goito et al. ${ }^{21}$ reported that the bite force was 
greatest at central incisors and first molar regions. According to the rule of 1:1:2 (incisor:premolar:molar), a maximum bite force of $2,500 \mathrm{~N}$ in a bruxism patient indicates that there is a force of $1,000 \mathrm{~N}$ in the first molar tooth region. ${ }^{19}$ Ayranci et al. ${ }^{9}$ simulated the bite forces of patients with bruxism and loaded 1,000 N. Previous studies examined angles of oblique force of $30,45,60$, and 75 degrees. ${ }^{9,20,22-24}$ In the present study, implants were loaded at $1,000 \mathrm{~N}$ vertically. To simulate lateral movements, a 30-degree angle force was applied. In common with the findings in the present study (Table 2), previous research showed that oblique forces increased von Mises stress values. 1,9,20,22

\section{D-FEA and limitations}

In the present study, all the models (cortical bone, trabecular bone, implant, abutment and srew) were assumed to be homogeneous and isotropic and to have linear elasticity. However, this is not the case under in vivo conditions. ${ }^{25}$ Furthermore, only an Inter-X connection design and static force were used in present study. In addition, a 100\% implant-bone interface was simulated, which is impossible in clinical situations. ${ }^{25}$

\section{CONCLUSION}

Zirconium connection screw may be applied in bruxism patients because it is resistant to high biting force. Preferring this material instead of titanium with appropriate planning will increase aesthetics.

\section{ABBREVIATIONS}

3D-FEA: Three dimension finite element analysis

Ti: Titanium

DICOM: Digital imaging and communications in medicine

$\mathrm{mm}$ : Milimeter

Y-TZP: Yttria stabilized zirconia

MPa: Megapascal

$\mathrm{N}$ : Newton

Z(I-A-S)v: Implant, abutment and connection screw are zirconia in vertical loads. 


\section{REFERENCES}

1. Villabona CA, Amorin Vasco MA, Ruales E, Bedoya KA, Benfatti CM, Bezzon OL, et al. ThreeDimensional Finite Element Analisys of Stress Distribution in Zirconia and Titanium Dental Implants. The Journal of oral implantology. 2018.

2. Ozkurt Z, Kazazoglu E. Zirconia dental implants: a literature review. The Journal of oral implantology. 2011;37(3):367-76.

3. Borgonovo AE, Censi R, Vavassori V, Dolci $M$, Calvo-Guirado JL, Delgado Ruiz RA, et al. Evaluation of the success criteria for zirconia dental implants: a four-year clinical and radiological study. International journal of dentistry. 2013;2013:463073.

4. Pieralli S, Kohal RJ, Jung RE, Vach K, Spies BC. Clinical Outcomes of Zirconia Dental Implants: A Systematic Review. Journal of dental research. 2017;96(1):38-46.

5. Bankoglu Gungor M, Yilmaz H. Evaluation of stress distributions occurring on zirconia and titanium implant-supported prostheses: A threedimensional finite element analysis. The Journal of prosthetic dentistry. 2016;116(3):346-55.

6. Choi AH, Matinlinna JP, Ben-Nissan B. Finite element stress analysis of Ti-6Al-4V and partially stabilized zirconia dental implant during clenching. Acta odontologica Scandinavica. 2012;70(5):353-61.

7. Kohal RJ, Att W, Bachle M, Butz F. Ceramic abutments and ceramic oral implants. An update. Periodontology 2000. 2008;47:224-43.

8. Rodriguez AE, Monzavi M, Yokoyama CL, Nowzari H. Zirconia dental implants: A clinical and radiographic evaluation. Journal of esthetic and restorative dentistry : official publication of the American Academy of Esthetic Dentistry [et al]. 2018.

9. Ayranci $F$, Sivrikaya EC, Omezli MM. Is bone density or implant design more important in implant stress formation in patients with bruxism? Biotechnol Biotec Eq. 2017;31(6):1221-5.

10.Van der Zaag J, Lobbezoo F, Van der Avoort PG, Wicks DJ, Hamburger HL, Naeije M. Effects of pergolide on severe sleep bruxism in a patient experiencing oral implant failure. Journal of oral rehabilitation. 2007;34(5):317-22.

11. Zhou Y, Gao J, Luo L, Wang Y. Does Bruxism Contribute to Dental Implant Failure? A Systematic Review and Meta-Analysis. Clinical implant dentistry and related research. 2016;18(2):410-20.

12. Sivrikaya EC, Omezli MM. The Effect Of Tapered And Cylindrical Implants On Stress Distribution In Different Bone Qualities: A Finite Element Analysis. The International journal of oral \& maxillofacial implants. 2019;34(6):e99-e105.
13. Osman RB, Elkhadem AH, Ma S, Swain MV. Titanium versus zirconia implants supporting maxillary overdentures: three-dimensional finite element analysis. The International journal of oral \& maxillofacial implants. 2013;28(5):e198-208.

14. Kourtis S, Damanaki M, Kaitatzidou S, Kaitatzidou A, Roussou V. Loosening of the fixing screw in single implant crowns: predisposing factors, prevention and treatment options. Journal of esthetic and restorative dentistry : official publication of the American Academy of Esthetic Dentistry [et al]. 2017;29(4):233-46.

15. da Silva LH, Ribeiro S, Borges AL, Cesar PF, Tango RN. FEA and microstructure characterization of a one-piece Y-TZP abutment. Dental materials : official publication of the Academy of Dental Materials. 2014;30(11):e283-8.

16. Macedo JP, Pereira J, Vahey BR, Henriques B, Benfatti CA, Magini RS, et al. Morse taper dental implants and platform switching: The new paradigm in oral implantology. European journal of dentistry. 2016;10(1):148-54.

17. Hisbergues M, Vendeville S, Vendeville P. Zirconia: Established facts and perspectives for a biomaterial in dental implantology. Journal of biomedical materials research Part B, Applied biomaterials. 2009;88(2):519-29.

18.Datte CE, Tribst JP, Dal Piva AO, Nishioka RS, Bottino MA, Evangelhista AM, et al. Influence of different restorative materials on the stress distribution in dental implants. Journal of clinical and experimental dentistry. 2018;10(5):e439-e44.

19. Gore E, Evlioglu G. Assessment of the effect of two occlusal concepts for implant-supported fixed prostheses by finite element analysis in patients with bruxism. The Journal of oral implantology. 2014;40(1):68-75.

20.Bozkaya D, Muftu S, Muftu A. Evaluation of load transfer characteristics of five different implants in compact bone at different load levels by finite elements analysis. The Journal of prosthetic dentistry. 2004;92(6):523-30.

21. Goiato MC, dos Santos DM, Santiago JF, Jr., Moreno A, Pellizzer EP. Longevity of dental implants in type IV bone: a systematic review. International journal of oral and maxillofacial surgery. 2014;43(9):1108-16.

22.Akca K, Iplikcioglu $H$. Finite element stress analysis of the influence of staggered versus straight placement of dental implants. The International journal of oral \& maxillofacial implants. 2001;16(5):722-30.

23. Ciftci $Y$, Canay $S$. The effect of veneering materials on stress distribution in implant-supported fixed prosthetic restorations. The International journal of oral \& maxillofacial implants. 2000;15(4):571-82. 
24.Gharechahi J, Sharifi E, Aghdaee NA, Nosohian S. Finite element method analysis of the stress distribution to supporting tissues in a Class IV Aramany removable partial denture (Part I: the teeth and periodontal ligament). The journal of contemporary dental practice. 2008;9(6):65-72.

25. Koca OL, Eskitascioglu G, Usumez A. Threedimensional finite-element analysis of functional stresses in different bone locations produced by implants placed in the maxillary posterior region of the sinus floor. The Journal of prosthetic dentistry. 2005;93(1):38-44.

26. O'Brien WJ. Dental materials and their selection. 2nd ed. Chicago: Quintessence Pub. Co.; 1997. xii, 421 p. p.

27.Geng JP, Tan KB, Liu GR. Application of finite element analysis in implant dentistry: a review of the literature. The Journal of prosthetic dentistry. 2001;85(6):585-98.

28.Sevimay $M$, Turhan $F$, Kilicarslan MA, Eskitascioglu G. Three-dimensional finite element analysis of the effect of different bone quality on stress distribution in an implant-supported crown. The Journal of prosthetic dentistry. 2005;93(3):227-34.

29. Raimondi MT, Vena P, Pietrabissa R. Quantitative evaluation of the prosthetic head damage induced by microscopic third-body particles in total hip replacement. Journal of biomedical materials research. 2001;58(4):436-48

\section{Corresponding Author:}

Efe Can SivRiKAYA

Karadeniz Technical University Faculty of Dentistry

Department of Oral Maxillofacial Surgery,

Trabzon, Turkey

E-mail : efecans@msn.com 